\title{
The Influence of Tuition Fees on the Choice of University among Senior High School Graduates in Kumasi, Ghana
}

\author{
Edward Gyamfi ${ }^{1}$, Isaac Gyamfi ${ }^{2} \&$ Du K. Qi ${ }^{1}$ \\ ${ }^{1}$ School of Economics and Management, Nanjing University of Science and Technology, Nanjing, P. R. China \\ ${ }^{2}$ Valley View University, Kumasi, Ghana \\ Correspondence: Edward Gyamfi, School of Economics and Management, Nanjing University of Science and \\ Technology, Nanjing, P. R. China. E-mail: edwardgyamfi180@yahoo.com
}

Received: July 29, 2016

doi:10.5539/ijbm.v11n12p222
Accepted: October 18, 2016 Online Published: November 20, 2016

URL: http://dx.doi.org/10.5539/ijbm.v11n12p222

\begin{abstract}
The study focused on the factors that influence senior high school (SHS) graduates' choice of university selection in Ghana. The 7ps, including product, price, place, process, promotion, people and physical evidence were chosen as the service marketing mix elements. This work was guided by whether or not tuition fees have a significant influence on SHS graduates' choice on the selection of university in Ghana.

In this study, the researchers used descriptive approach to analyze the work due to the fact that the study seeks to pinpoint the factors that influence students' choice on the selection of university in Ghana. The population of the study was mainly final year students in the Kumasi Metropolis and the sample size was made up of three hundred and thirty-five (335) of such students. The study employed questionnaire and multi-stage sampling as a means of data collection instrument which was used to develop insights that supplemented the results of the statistical analysis. Statistical Package for the Social Sciences (SPSS) version 16 was used to analyze the data. The study concludes that the program (product) element of the marketing mix is the main factor that influences SHS graduates' choice of university in Ghana with a percentage of 32.8 followed by process which accounted for $28.10 \%$. The study recommends that universities in Ghana particularly private universities should put in place tailor-made programs that can contribute to the acquisition of high employable skills by students and also strengthen their Quality Assurance Departments.
\end{abstract}

Keywords: university choice, Ghana, marketing mix, educational marketing, senior high school

\section{Introduction}

The body of an increased competitiveness and privatization in the institutions of higher learning coupled with the emergence of private universities in Ghana calls for identification of factor (s) that influence graduates of Senior High School (SHS) in their choice of university. This phenomenon has affected the operations of both the private and public universities across the globe (Maringe, 2006). In the past, only government institutions were in existence to offer undergraduate and post graduate to those who qualified and wanted higher education. The growing numbers of universities has given potential students a lot of universities to select from, the need for the universities to distinguish themselves from rivalry is undeniable, this has increased the role of marketing in the recruitment of students (Ivy, 2008), and Ghana is no exception Again, the reduction in the enrolment by the government institutions and the decrease in government funds for higher education has increased the chances for the private institutions. There have been changes in Ghana's educational sector since the emergence of private institutions (Mkude, Cooksey, Levey, \& Pereira, 2004).

The role of marketing mix elements in enrolment drive has therefore become very crucial to the survival of not only private universities but state owned universities as well. This argument is reinforced by (Kotler, P. \& Armstrong, 2008) who posit that marketing mix is considered one of the key principles which holds the foundation of every marketing strategy. By implication, both the private and public universities must recognize which element of the marketing mix most influences students' choice of a university in Ghana. (Little, O'Toole, \& Wetzel, 1997) and (Ratshinga, 1998) wrote that the fees which is charged for pursing a degree or tuition is the main factor that influences the decision of a student to enroll at a university. They contend that pricing element influences students' perceptions of quality. Again, according to (Peter \& Donnelly, 2011) customers focus more 
on price than other attributes in the developing countries like Ghana. (Bowie \& Buttle, 2004) also claim that Price is a key measure of quality, particularly service industry where there are no tangible cues to measure quality. The verdict from the above authors seems to suggest that in the developing countries like Ghana, price (tuition fees) is the main determinant of brand choice among SHS graduates.

However, the scenario on the education system and choice of the university is quite different toady. So in this paper we present the influence of tuition fee on the SHS graduates for choice of university on Ghana based on our case study in the Kumasi metropolis.

\subsection{Problem Statement}

Higher education in Ghana today is characterized with privatization and competition. This new phenomenon has given students preferences and therefore factors which influence students choice of university selection has become an important subject. Due to this, most universities in Ghana today seem to be relying more on price (tuition fees) to enhance their enrolment drive. The verdict from the above authors seems to suggest that in the developing countries like Ghana, price (tuition fees) is the main determinant of brand choice among students.

However, it must be noted that the picture as painted by the above authors may not be entirely effective today. Therefore, there is the need to study the factors that influence SHS graduates' choice of university. So the multi-billion dollar question is, does tuition fee influence SHS graduates' choice of university in Ghana?

\section{Related Works}

\subsection{Educational Marketing}

Marketing mix for higher education was the principal conceptual framework which was assumed for this paper, particularly on what is described as the $7 \mathrm{ps}$ model by (Kotler \& Fox, 1995). Whether educational institution ought to take part in marketing or not has been debated a lot these days (Bartlett, Frederick, Gulbrandsen, \& Murillo, 2002; Dirks, 1998). Marketers aim at achieving profit so education cannot be marketed, particularly with the higher education because a lot of these institutions do not operate for profit.

Also, some of the researchers who opposed to the idea of educational marketing agree that, marketing higher education will make the educational institution to emphasize on organizational efficacy rather than social equity. Customer satisfaction will be basically ascertained by accountability. This line of thought is contended by (Agasisti \& Catalano, 2006) who argued that higher education should be marketed, propose that in the developed countries especially, the government interference is minimal and the concept of marketing in institutions of higher learning is not a new phenomenon particularly with the fact that universities have to compete for students and funds. This viewpoint is also shared by (Drummond, 2004; Husbands \& Bridges, 2005; Pugsley, 2004). Again, (Gibbs, Pashiardis, \& Ivy, 2008) posit that the emergence of public and private institutions has increase the selection mode of potential students in terms of selecting universities, as result of this the recruitment of students in both developed and developing economies have been intensified by the role of marketing.

Again, the activities of educational institutions depend on the money charge from tuition or source of funds from the state or others. To prove this argument, (Pasternak, 2005) claims that, higher education is being marketed as the same as any other service or product in modern societies. The process in which customers choose a product or service is similar to students when they also want to obtain higher knowledge, because they also consider the benefit over the cost. The researchers cannot help but agree that higher education must be marketed. The marketing mix elements in education are product/program, price, place, promotion, people, processes and physical evidence.

\subsection{Product/Program}

The first element of the marketing mix is Product. (Kotler \& Fox, 1995) substituted product with program in their version of marketing mix which was developed particularly for higher education. Many scholars, including (Hesketh \& Knight, 1999), (bin Yusof, binti Ahmad, bin Mohamed Tajudin, \& Ravindran, 2008), (Gibbs \& Knapp, 2002) agree with (Kotler \& Fox, 1995) that product should be replaced with program in the context of higher education and have contributed to the influence of academic programs on students' choice of higher education. According to (Kotler \& Fox, 1995) the quality of academic programs significantly influences students' choice of higher education. (Ferrell \& Hartline, 2011) also posit that product is the core of any marketing mix strategy. They argue that without product there is no need for pricing, promotion and distribution. However, organizations can differentiate themselves from the competition through extended benefits of their services like helpful and polite personnel (Mahmood \& Khan, 2014). Products or services are made up of three components which create unique benefit to the customer. 


\subsection{Price}

The price is the second element of the marketing mix. Price is the monetary value place on a product; direct and indirect cost in addition to profit (Kotler \& Armstrong, 2008). In the viewpoint of education, (Hayes, 2009) defined price as the amount of money in which a student pay to acquire education. He further explained that price comprises the tuition, loan, grant or scholarship alongside with such non-financial costs like time, inconveniences and distance between the university and the resident of the student. A lot of researchers including (Beneke \& Human, 2010; Domino, Libraire, Lutwiller, Superczynski, \& Tian, 2006; Wagner \& Fard, 2009) have all examined the influence of price on students' choice of a university. Pricing can make or unmake a business. For example if a price cannot meet the cost of producing the product, then loss will occur and eventually a firm will go out of business if it continues, however, if the price is too high than customers can afford the business is likely to fold up (Kotler \& Armstrong, 2008).

\subsection{Promotion}

(Kotler \& Armstrong, 2010) argued that Promotion is the act of making customers aware of the product or services, and what can be done to help them. Promotion helps educational institution in differentiating its services offered on the minds of its prospective customers. The product or service offered by organizations becomes useless if customers and potential customers are not aware of it's existence. Customers can only buy what they know therefore the researchers are of the opinion that organizations can influence customer's choice through effective and persuasive communication. Promotion in education sector includes the ways in which universities use to create awareness of their services available to the target market (Ivy, 2008). Some universities communicate to their potential students and parents through public relations, advertisements and publicity.

\subsection{Place}

Place is an important element of the marketing mix. (Brassington \& Pettitt, 2006) defines place as the system of delivery and distribution channels of service. The distribution of service should be easily accessible and available to prospective students. Furthermore, in service marketing the convenient location and accessibility of an educational institution to the students also relates to place. (Ivy \& Naude, 2004) and (Maringe, 2006) relate place to the environment in which the university is located.

\subsection{People}

People in marketing mix represent every individual or group of people who are involved in the delivery of the service. In the education sector, they include teaching and non-teaching staff and other consumers who often add significant value to the total service offering. People have an important role in the process of delivering service since the service cannot be separated from its provider. Service is defined by people. According to (Hinson, 2006) the attitude, skills, appearance, and dressing of all the staffs influence the customers' mindset of the service. (Ivy $\&$ Naude, 2004) people (lecturers, registrars, heads of departments, etc) as an element of service marketing mix does not have much influence on potential students. This argument is sharply contested by researchers such as (Brassington \& Pettitt, 2006), (Hollensen, 2003) and (Kotler \& Fox, 1995) who argues that people element mix in higher institutions has a significant influence on prospective students.

\subsection{Process}

The systems in which an institution use to deliver it service is known as process, this element of marketing mix is the utmost importance and it relates to the entire administrative system (Kotler, P. \& Keller, 2009). This talks about the ways in which things take place in an institution, such as application process, which includes acquisition of admission forms, the process of registration, teaching style, social events and sporting activities (Frimpong \& Kofi, 2014). (Palmer, 2001) specified that customers of manufactured products might show a little concern to the processes, nonetheless, they are of critical concern to high contact services such as education. Service delivery has been greatly shaped by technology in recent times (Mahmood \& Khan, 2014). They additionally stated that the creation of value, reduction in cost and differentiation of services to customers has being made easy due to advance technology.

\subsection{Physical Evidence}

The physical evidence of the marketing mix represents the environment in which the service is being delivered (Hinson, 2006). Physical amenities display a serious role within the promotion of education because it is this way in which an organization can possibly intensify the tangibility of its offering and also establish a positive experience, particularly with the actual fact that there's no typically abundant to be examined before acquisition (Gibbs \& Knapp, 2002). Facilities such as the building, modernized offices, interior and exterior designs and decorations, and also the location of the institution are involved. (Hayes, 2009) points out that parents and 
students measure and gets assurance on the quality of education from physical evidences mostly based on the facilities of the educational institution.

\subsection{Student as Customer}

Some researchers assume that students cannot be classified as customers (Sharrock, 2000). This contention is seen to be substantial in a circumstance where there is no competition and all the advanced education is being financed by the government. (Yeo, 2008) proposes two separate ideas of students as customers for instance, the individuals who view students as essential clients, partner them as being required in the input and output of the learning procedure. In any case, the individuals who see students as potential managers as essential clients contend that it is critical to consider the monetary reality of the circumstance where lesson substance ought to be custom fitted to employers' needs. Students in this perspective have being viewed as internal customers. (Jaraiedi \& Ritz, 1994) additionally contended that students have no idea of what they have to learn: all things considered, education is setting them up for the long haul advantages without bounds. It is with this long-term assessment that Potential employers are viewed as primary customers whereas students are viewed as secondary customers. In another opinion, students have been classified as the essential recipients of education and, subsequently, ought to be dealt with as clients. This point of view curtails from the understanding that instructive institutions are exceptionally focused on the market with techniques being forcefully created to fulfill student needs so as to entice a maintainable market share (Joseph \& Joseph, 2000).

\section{Research Methods}

The research design employed in this work was descriptive which was intended to assess the influence of tuition fees on SHS graduates' choice of university. The target population of the study was composed of final year SHS students in the Kumasi Metropolis because it was assumed that their next level of education is the university and have already made decisions on their choices of university to attend. The sample population for the study was made up of final year students from Opoku Ware Senior High School (OWASS), Kumasi Senior High School (KUHIS), Kumasi Girls' Senior High School (KUGIS), Kumasi Senior High Technical School (KSTS) and Yaa Asantewaa Girls' Senior High School (YAGGS). It is important to mention that the population was a composition of people with varied background characteristics in terms of age, sex, programs offered, ethnicity and religion.

The sampling method employed for the study was Multi-stage. This sampling technique was used because the population is large and extensive. In finding the sample size of respondents, a mathematical approach was adapted. The sample size was estimated using (Krejcie \& Morgan, 1970) sample size determination table based on the sample size determination formulae developed by the NEA (1960). In all 335 SHS students were selected from five SHS and this is shown below:

$$
n=N /\left(1+N e^{2}\right)
$$

where $\mathrm{n}$ is the sample size for customers, $\mathrm{N}$ is the population of respondents and e represents the level of precision (5\% margin of error). From equation (1) above, with a respondent population of two thousand and fifty six (2056) and at a five percent (5\%) margin error, the sample size, $\mathrm{n}$ was estimated to be approximately three hundred and fifty five (355).

In this survey, a self-completion questionnaire with twenty-one (21) closed ended questions and one open ended question were developed. All the twenty-two (22) questionnaire items were Likert-type and one open ended item. The 22 items on "the influence of marketing mix elements on the choice of university" were on scales from "not important at all" not important" "uncertain ", "important", and "very important", were assigned ordinal values of 1,2,3,4 and 5, respectively. All the likert-type items used a five-point scale that has been suggested by (Anderson, 1985). The researchers used a five-point scale because such a scale encourages respondents to make decisions "freely" from a number of responses (Anderson, 1985; Casley \& Kumar, 1988). The researchers selected five (5) SHS in the Kumasi Metropolis. The questionnaire was administered to final year students who had only two terms to complete their SHS programs. The researcher chose this form of data collection instrument because it is more flexible than interview guide. Data analysis technique was descriptive. Statistical Package for the Social Sciences (SPSS) program was chosen to process analyze the data. In order to help the reader to follow the data analysis, the researchers conducted the data analysis in steps. In order to achieve the main objective of this study which was to find out the influence of tuition fees on the choice of university among Senior High School graduates, the research question; does tuition fee has a significant influence on the choice of university among SHS graduates in Ghana was posed? This research question sought information on marketing mix elements such as product, price, promotion, place, people and processes. 
In order to answer this research question, a five-point Likert scale was used to assess the influence of tuition fees on the choice of university among SHS students in Ghana. The computed means were then compared with the theoretical mean (assuming the normal distribution of responses) of 2.50 to decide how each of the of the marketing mix elements influences students' choice of university.

\section{Results}

The result was computed using descriptive statistics that is making use of Statistical Package for the Social Sciences (SPSS). Table 1 and Figure 1 present response from the respondents.

Table 1. Influence of marketing mix elements on student's choice of university

\begin{tabular}{lcccc}
\hline Marketing Mix Element & $\mathrm{N}$ & Mean & Std. Deviation & Std. Error Mean \\
\hline university education & 335 & 4.11 & .977 & .053 \\
perceived quality of programs & 335 & 4.11 & .730 & .040 \\
availability of online programs & 335 & 4.06 & .633 & .035 \\
no of courses taken & 335 & 4.13 & .600 & .033 \\
affordable tuition fees & 335 & 2.84 & .789 & .043 \\
paying tuition in installments & 335 & 2.75 & .777 & .042 \\
possibility of getting scholarship & 335 & 2.75 & .768 & .042 \\
accommodation options & 335 & 1.75 & .655 & .036 \\
multiple campuses & 335 & 1.72 & .619 & .034 \\
transportation cost to the university & 335 & 1.77 & .658 & .036 \\
advertisement about the university & 335 & 1.75 & .655 & .036 \\
flexible time table & 335 & 2.96 & 1.130 & .062 \\
entry requirements & 335 & 3.16 & .913 & .050 \\
availability of course materials & 335 & 2.17 & .825 & .045 \\
online semester registration & 335 & 3.07 & .890 & .049 \\
university infrastructure & 335 & 3.14 & .906 & .050 \\
technology and internet infrastructure & 335 & 2.00 & .802 & .044 \\
laboratory facilities & 335 & 1.77 & .849 & .046 \\
high caliber staff & 335 & 1.45 & .571 & .031 \\
how lectures are delivered & 335 & 1.44 & .596 & .033 \\
good student - staff relationship & 334 & 1.43 & .526 & .029 \\
\hline
\end{tabular}

Source: Field Data, 2016.

From Table 1, among the seven (7) elements of marketing mix only product and price elements significantly influences students' choice of university above the theoretical mean of $2.50(x=4.102$ and 2.780$)$ respectively. People element of marketing has the least influence on students' choice of university with a theoretical mean far below $2.50(\mathrm{x}=1.450)$. This research finding is consistent with research report by (Ivy \& Naude, 2004) which revealed that individuals are not weighted to be a compelling component in the blend with respect to forthcoming understudies. The results also showed that Product element of marketing mix most influences students' choice of university with a theoretical mean of $x=4.102$ well above the theoretical mean of 2.50 . This results reveals that the program that has the most important impact on students choice of university contradicts the research findings by (Little et al., 1997) and (Ratshinga, 1998) who stated that fees charge for tuition or a degree is the main factor that influences the decision of a student to enroll at a university. 


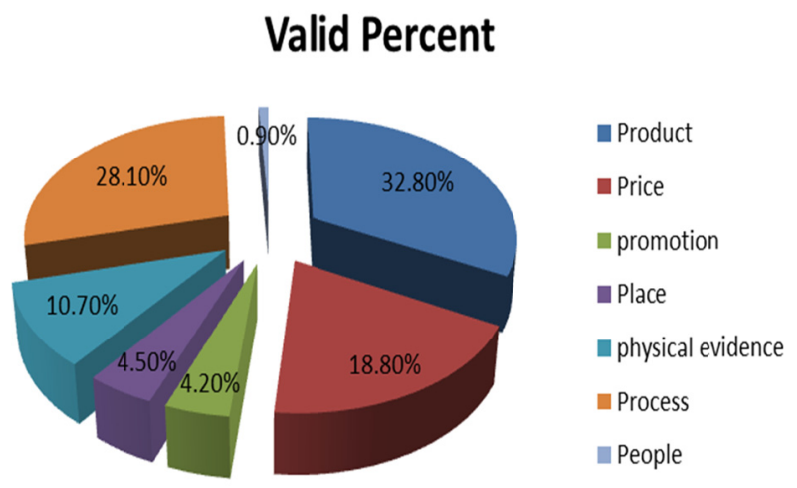

Figure 1. Elements SHS graduates in the Kumasi Metropolis considers most important

The response from the survey according to Figure 1 reveals that SHS graduates considers process which accounted for $28.1 \%$ as the second most important element in their choice of school followed by price (tuition), physical evidence, people, place and promotion representing $18.8 \%, 10.7 \%, 9 \%, 4.5 \%$ and $4.2 \%$, respectively. This research finding is consistent with (Palmer, 2001) research which reported that there are critical concern to high contact services such as education since the processes may be of little concern to customers of manufactured products.

\section{Conclusions}

With the changing trends in higher education, the choice of student for a particular university may be based on many different factors but this paper focused on the $7 \mathrm{p}$ factors of product, price, promotion, people, place, process, physical evidence which are likely to influence the Ghanaian Senior High Schools graduates' choice of a university to attend. From the result of the study it can be concluded that SHS graduates are influenced by the product element of marketing mix in their choice of university. Generally, SHS graduates in the Kumasi Metropolis in Ghana are mainly influenced by the product element of universities which is the quality of programs offered by the university. Even though the findings in this study may not represent the global trends on the subject, yet it confirms what (Ferrell \& Hartline, 2011) asserted. They stated that the product is the core of the marketing mix strategy because without a product there is no need for pricing, promotion and distribution. This also contradicts the views of (Little et al., 1997) who posited that price (tuition fee) does significantly influence students' choice of university which ranked as the third most important factor in students choice of a university. Students also consider processes as very important in their choice of university. This is an indication student are keen about the ways in which things take place in an institution, such as tuition, sporting etc. , processes are very important. This confirms the assertion by Palmer (2001), who specified that customers of manufactured products might be of a little concern with the processes, nonetheless, they are of critical concern to high contact services such as education. In view of these, tertiary establishments in Ghana especially private ones ought to consider offering competitive and cut-edge programs to position them as relevant players in the industry and to attract more students. Also, institutions must strengthen their Quality Assurance Department in order to ensure that processes in the institution are well followed by all players in the establishment. Also both public and private universities in Ghana particularly the private ones are recommended to critically consider the best ways to present their services in order to make them more appealing to their target audience. Whilst this paper is a starting point, more research is needed in the Ghanaian tertiary context with deeper levels of analysis including the class of program fields/disciplines that are likely to attract students.

\section{Acknowledgements}

The authors of this paper wishes to thank Dr. Nana Agyemang Prempeh-Nanjing University of Information Science and Technology, China P.R. and Mr. Kyeremeh Frimpong-Nanjing Technology University, China P.R. for their immense and outstanding intellectual contributions to this manuscript.

\section{References}

Agasisti, T., \& Catalano, G. (2006). Governance models of university systems-towards quasi-markets? Tendencies and perspectives: A European comparison. Journal of Higher Education Policy and 
Management, 28(3), 245-262. http://dx.doi.org/10.1080/13600800600980056

Anderson, L. W. (1985). Likert scales: International encyclopedia of education (Vol. 5, pp. 3082-3084). Oxford: Pergamon.

Bartlett, L., Frederick, M., Gulbrandsen, T., \& Murillo, E. (2002). The marketization of education: Public schools for private ends. Anthropology \& Education Quarterly, 5-29. http://dx.doi.org/10.1525/aeq.2002.33.1.5

Beneke, J., \& Human, G. (2010). Student recruitment marketing in South Africa-An exploratory study into the adoption of a relationship orientation. African Journal of Business Management, 4(4), 435.

Bin Yusof, M., binti Ahmad, S. N. B., Bin Mohamed Tajudin, M., \& Ravindran, R. (2008). A study of factors influencing the selection of a higher education institution. UNITAR E-Journal, 4(2), 27.

Bowie, D., \& Buttle, F. (2004). Hospitality marketing: An introduction. Routledge. http://dx.doi.org/10.1016/b978-0-7506-5245-2.50006-7

Brassington, F., \& Pettitt, S. (2006). Principles of marketing. Pearson Education.

Casley, D. J., \& Kumar, K. (1988). The collection, analysis and use of monitoring and evaluation data. The World Bank.

Dirks, L. (1998). Higher education in market theory. Retrieved from http://webhost.Bridgew.Edu/adirks/ald/papers/mktheor

Domino, S., Libraire, T., Lutwiller, D., Superczynski, S., \& Tian, R. (2006). Higher education marketing concerns: Factors influence students' choice of colleges. The Business Review, 6(2), 101-111.

Drummond, G. (2004). Consumer confusion: Reduction strategies in higher education. International Journal of Educational Management, 18(5), 317-323. http://dx.doi.org/10.1108/09513540410543466

Ferrell, O. C., \& Hartline, M. D. (2011). Marketing Strategy (5th ed.). Mason, OH: South-Western: Cengage learning.

Frimpong, F., \& Kofi, F. (2014). Exploring the Factors That Influence Students' Choice of Higher Education in Ghana, 6(28), 209-220.

Gibbs, P., \& Knapp, M. (2002). Marketing higher and further education. British Library Cataloguing in Publication Data.

Gibbs, P., Pashiardis, P., \& Ivy, J. (2008). A new higher education marketing mix: The 7Ps for MBA marketing. $\begin{array}{llll}\text { International Journal of Educational } & \text { Management, 22(4), }\end{array}$ http://dx.doi.org/10.1108/09513540810875635

Hayes, T. J. (2009). Marketing colleges and universities: A services approach. Case.

Hesketh, A. J., \& Knight, P. T. (1999). Postgraduates' choice of programme: Helping universities to market and postgraduates to choose. Studies in Higher Education, 24(2), 151-163. http://dx.doi.org/10.1080/03075079912331379858

Hinson, R. (2006). Marketing of Services: A Managerial Perspective. Sedco, Accra.

Hollensen, S. (2003). Marketing management : A relationship approach. Harlow, England, New York: Financial Times/Prentice Hall.

Husbands, C., \& Bridges, D. (2005). Consorting and collaborating in the education market place. Routledge.

Ivy, J. (2008). A new higher education marketing mix: The 7Ps for MBA marketing A new higher education marketing mix: The 7Ps for MBA marketing, (May 2008). http://doi.org/10.1108/09513540810875635

Ivy, J., \& Naude, P. (2004). Succeeding in the MBA marketplace: Identifying the underlying factors. Journal of Higher Education Policy and Management, 26(3), 401-417. http://dx.doi.org/10.1080/1360080042000290249

Jaraiedi, M., \& Ritz, D. (1994). Total quality management applied to engineering education. Quality Assurance in Education, 2(1), 32-40. http://dx.doi.org/10.1108/09684889410054563

Joseph, M., \& Joseph, B. (2000). Indonesian students' perceptions of choice criteria in the selection of a tertiary institution: strategic implications. International Journal of Educational Management, 14(1), 40-44. http://dx.doi.org/10.1108/09513540010310396 
Kotler, P., \& Armstrong, G. (2008). Principles of Marketing (12th ed). Upper Saddle River, NJ: Pearson/Prentice Hall.

Kotler, P., \& Armstrong, G. (2010). Principles of marketing. Pearson Education.

Kotler, P., \& Fox, F. A. (1995). Karen; Strategic Marketing for Educational Institutions. Prentice Hall, Inc New Jersey.

Kotler, P., \& Keller, K. L. (2009). Marketing Management. Upper Saddle River. New Jersey: Pearson Prentice Hall.

Krejcie, R. V., \& Morgan, D. W. (1970). Activities, 38, 607-610.

Little, M. W., O'Toole, D., \& Wetzel, J. (1997). The Price Differential's Impact on Retention, Recruitment, and Quality in a Public University. Journal of Marketing for Higher Education, 8(2), 37-51. http://doi.org/10.1300/J050v08n02_04

Mahmood, R., \& Khan, S. M. (2014). Impact of Service Marketing Mixes on Customer Perception: A Study on Eastern Bank Limited, Bangladesh. European Journal of Business and Management, 6(34), 164-167.

Maringe, F. (2006). University and course choice Implications for positioning, recruitment and marketing. International Journal of Educational Management, 20(6), 466-479. http://doi.org/10.1108/09513540610683711

Mkude, D., Cooksey, B., Levey, L., \& Pereira, C. (2004). Change \& Transformation in Ghana's Publicly Funded Universities Higher Education in Africa.

Palmer, A. (2001). Principles Of Services Marketing. UK (United Kingdom): McGraw-Hill Companies.

Pasternak, R. (2005). Choice of institutions of higher education and academic expectations: The impact of cost-benefit factors. Teaching in Higher Education, 10(2), 189-201. http://dx.doi.org/10.1080/1356251042000337945

Peter, J. P., \& Donnelly, J. H. (2011). Marketing management: knowledge and skills: Text, analysis, cases, plans.

Pugsley, L. (2004). The university challenge: Higher education markets and social stratification. Gower Publishing, Ltd.

Ratshinga, M. T. (1998). Higher fees make for few students.

Sharrock, G. (2000). Why students are not (just) customers (and other reflections on life after George). Journal of Higher Education Policy and Management, 22(2), 149-164. http://dx.doi.org/10.1080/713678141

Wagner, K., \& Fard, P. Y. (2009). Factors influencing Malaysian students' intention to study at a higher educational institution. E-Leader Kuala Lumpur.

Yeo, R. K. (2008). Brewing service quality in higher education: Characteristics of ingredients that make up the recipe. Quality Assurance in Education, 16(3), 266-286. http://dx.doi.org/10.1108/09684880810886277

\section{Copyrights}

Copyright for this article is retained by the author(s), with first publication rights granted to the journal.

This is an open-access article distributed under the terms and conditions of the Creative Commons Attribution license (http://creativecommons.org/licenses/by/4.0/). 